\title{
Tempo de infância num lugar do avesso: dez anos de estórias no Espaço Lúdico Terapêutico
}

\section{A time for childhood through the looking-glass: ten years of stories at the "Espaço Lúdico Terapêutico"}

\author{
Maria Isabel Garcez Ghirardi ${ }^{1}$
}

O tempo perguntou ao tempo qual é o tempo que o tempo tem. E o tempo respondeu ao tempo que o tempo tem o tempo que o tempo tem.

(Ditado Popular)

\begin{abstract}
GHIRARDI, M. I. G. Tempo de infância num lugar do avesso: dez anos de estórias no Espaço Lúdico Terapêutico. Rev. Ter. Ocup. Univ. São Paulo, v. 17, n. 1, p. 1-3, jan./abr. 2006.

RESUMO: O artigo pretende homenagear os dez anos de existência do Espaço Lúdico Terapêutico, considerando suas particularidades e enfatizando as inovações propostas por esse projeto, especialmente no que diz respeito a recuperar a dimensão da infância que fequientemente se perde nos tratamentos de reabilitação da deficiência.
\end{abstract}

DESCRITORES: Ludoterapia. Crianças portadoras de deficiência/reabilitação. Terapia ocupacional.

omemorar os dez anos de criação do Espaço Lúdico Terapêutico é um privilégio, uma vez que a composição desse espaço tem se mostrado uma tarefa delicada e inovadora não apenas no que diz respeito à clínica da terapia ocupacional, mas também em termos de relação social com a infância e adolescência com deficiência.

Lembro-me dos primeiros movimentos que instituíram esse Espaço. Naquela ocasião, as conversas giravam em torno de uma preocupação com a infância, com um lugar em que as crianças pudessem simplesmente experimentar brincadeiras, livres da classificação médica de seus limites ou de suas deficiências. Buscava-se algo como um cenário em que se desenvolvesse uma estória infantil em sua intrínseca complexidade, um lugar em que a deficiência fizesse parte do cenário, mas não definisse o roteiro das estórias de vidas que por ali viessem a circular.

Assim sendo, quase como uma brincadeira, foi se

${ }^{1}$ Professora do curso de Graduação em Terapia Ocupacional da FMUSP.

Endereço para correspondência: Departamento de Fisioterapia, Fonoaudiologia e Terapia Ocupacional da Faculdade de Medicina da Universidade de São Paulo. Rua Cipotânea, 51. Cidade Universitáira - CEP: 05360-000 - São Paulo, SP. 
constituindo, aos poucos, um lugar avesso às classificações clínicas, um lugar paradoxalmente avesso à deficiência, mas intensamente potencializador da ação infantil na cena social cotidiana. Um lugar que, ao contrário dos espaços de investigações clínicas, reconhecia a infância como protagonista e, assim, tornava possível experimentar diversas fantasias, muito além daquelas que a deficiência propõe.

O ELT inventa e propõe uma perspectiva de terapia ocupacional que parte da ação da criança e que, através da cartografia do movimento infantil, instaura um lugar existencial que pretende escapar das determinações vinculadas à deficiência. Para tanto, toma o cotidiano como espaço em que se promove rupturas com a paralisia instalada na cristalização temporal da inação e provoca o movimento, conjugando ousadia e delicadeza num mesmo momento.

Assim sendo, observou-se que o técnico também poderia, ao entrar nesse jogo, abandonar sua máscara de saber e reconhecer o próprio medo de se arriscar e de se experimentar em novas práticas que pretendem escapar de um cotidiano atravessado por relações estereotipadas com a deficiência, para dar lugar aos devaneios infantis.

Busca-se, então, a ruptura com o processo estigmatizante de relações rotineiras pautadas pela deficiência, pela incapacidade com o intuito de produzir alternativas que tenham origem no reconhecimento dos desejos e das necessidades da criança que se relaciona, que brinca e que fantasia a vida em gestos livres os quais engendram a singularidade de sua potência. Dessa maneira, também procura-se nesses gestos fendas pelas quais atravessar a parede da inércia em relação à criança e ao adolescente com deficiência, a fim de produzir um deslocamento na óptica positivista da deficiência e instalar a relação no âmbito da complexidade e da interdependência de sujeitos sociais diversos.

Assim, o Espaço Lúdico Terapêutico vem realizando uma certa subversão, ao propor que “(...) a criança abra um espaço em sua vida interior para a curiosidade, para o desfrute de sua imaginação e criatividade" (BRUNELLO, 2001, p.21). Mantendo a proposta de ser um outro lugar, um lugar em que crianças possam, em sua singularidade, escapar da captura subjetiva que impõe a deficiência como personagem.

Da maneira pela qual percebo esse Espaço, ousaria dizer que ele se propõe a ser um lugar do avesso. O avesso daquilo que freqüentemente é oferecido à população de crianças e adolescentes com algum tipo de deficiência em instituições de reabilitação. Nas palavras de Brunello (2001), o ELT pretende,

“(...) criar um espaço de experimentação das potencialidades individuais e coletivas de crianças e adolescentes com deficiência. Vivendo a criação, a partir do lúdico, num ambiente coletivo e livre, poderia cada criança desenvolver sua criatividade e espontaneidade, vivenciar situações novas e inesperadas permitindo-lhe lidar com novas emoções, sensações ou gestos, descobrindo espaços de expressividade (p. 31)”.

A complexidade desse lugar de brincar intensifica-se ao enfrentar as contradições impostas às práticas que pretendem escapar de uma certa colonização profissional, pautada pelo modelo médico-biológico, que privilegia o contato com a deficiência desencarnada, numa suspensão temporal em que a infância não pode existir.

Assim, o ELT parte do restabelecimento da tensão do desejo, para tornar-se um lugar “(...) de reconstrução de pontes, com o desejo, com o outro, com o fazer, com o mundo, lugar simplesmente de vida (BRUNELLO, 2001, p. 30)", espaço em que é possível brincar fora da ordem, espaço em que a potência do lúdico transgride a conformidade apaziguada da clínica da deficiência.

Sendo um espaço para fora, voltado para o outro, guarda a leveza da infância e garante a existência do tempo necessário para que diferentes estórias ganhem corpo e se manifestem na constituição de sujeitos diversos. Nesse enredo em que o lúdico joga com o vivido e o sentido, a estória do ELT vai se desenrolando através de ações e de movimentos que compõem uma perspectiva de terapia ocupacional que privilegia uma cartografia do movimento como forma de acesso ao outro e que considera a descontinuidade desses movimentos não lineares, como um ritmo constitutivo do humano.

O ELT parte de um mundo avesso às diferenças para construir um mundo de avessos, buscando percursos que evitem a retórica impositiva que pretende preparar $o$ indivíduo para a vida, como nos ensinam os manuais de reabilitação. O ELT inverte essa lógica ao abrir a vida para que novos acontecimentos possam ser matrizes de cotidianos em que sujeitos vivam suas próprias estórias, em meio às contradições de um mundo em movimento.

Trata-se, então, de inventar um cotidiano que tenha o lúdico e a infância como eixo, escapando, assim, das formas de controle da subjetividade a que estão expostas às crianças com deficiências. Resgatar o cotidiano, a infância e o lúdico como possibilidades singulares no contexto social, esse tem sido o desafio a que o ELT tem se exposto no decorrer desses dez anos.

O ELT supera o sentido do espaço terapêutico ao entender que a ação parte da brincadeira. Essa brincadeira constitui-se, então, como vetor e o movimento ganha potência, gerando um processo dinâmico de ação sobre o mundo. Transforma-se, assim, num espaço de resistência ao seqüestro do tempo da infância que a sociedade capitalista contemporânea tende a impor, ao estabelecer os ritmos e o 
tempo de brincar. Essa infância, que circula no ELT, tende a escapar do controle de um certo tipo de biopoder, ao encontrar ali um cenário para estórias nas quais o tempo faz parte da brincadeira e pode ser inventado e desdobrado na criação de uma poética que conhecemos pelo nome de infância.

GHIRARDI, M. I. G. A time for childhood through the looking-glass: ten years of stories at the "Espaço Lúdico Terapêutico". Rev. Ter. Ocup. Univ. São Paulo, v. 17, n. 1, p. 1-3, jan./abr. 2006.

ABSTRACT: This paper celebrates the tenth anniversary of story telling at the "Espaço Lúdico Terapêutico", looking at its peculiarities and highlighting the innovation such project represents, mainly in the ways it works to recover the dimension of childhood, something which is often lost in rehabilitation practices.

KEY WORDS: Play therapy. Disabled children/rehabilitation. Occupational therapy.

\section{REFERÊNCIAS}

BRUNELLO, M. I. B. Ser lúdico: promovendo a qualidade de vida na infância com deficiência. 2001. Tese (doutorado) - Instituto de Psicologia, Universidade de São Paulo, São Paulo, 2001.

Recebido para publicação: 16/01/06

Aceito para publicação: 07/02/06 